\title{
OPEN Synthesis and characterization of analcime (ANA) zeolite using a kaolinitic rock
}

\author{
Daniela Novembre ${ }^{1 \bowtie}$ \& Domingo Gimeno ${ }^{2}$
}

Analcime is nowadays an important component in dental porcelain systems, in heterogeneous catalysis, in the nanoelectronic field, in selective adsorption and in stomatology (dental filling and prosthesis). Analcime synthesis from an impure, silica-rich kaolinite rock coming from Romana (Sassari, Italy) is here presented. A synthesis protocol is proposed that aims to make an improvement of synthesis conditions compared to the past. The hydrothermal treatment is in fact here achieved without aging times and without the use of sodium silicate or other additional silica source reported in the literature. Lower calcination temperature, synthesis temperature and crystallization time are verified in this work. The kaolin is subjected to calcination at the temperature of $650^{\circ} \mathrm{C}$ and then mixed with $\mathrm{NaOH}$. The experiment is performed at ambient pressure and $170 \pm 0.1^{\circ} \mathrm{C}$. The degree of purity of analcime is calculated in $97.57 \%$ at $10 \mathrm{~h}$. Analcime is characterized by X-ray diffraction, infrared spectroscopy, scanning electron microscopy, inductively coupled plasma optical emission spectrometry and thermal analysis. Density is also calculated. Cell parameters and the amount of amorphous phase in the synthesis powders is estimated with quantitative phase analysis using the combined Rietveld and reference intensity ratio methods. The experimental conditions make the synthesis protocol particularly attractive from an economic point of view. Also this work does not use a commercial kaolin but silica-rich impure kaolinitic rock from a disused quarry. This further reduces the costs of the experimental protocol. It also gives the protocol an added value, as the synthesis of a useful mineral is obtained through the valorization of an otherwise unused georesource. Both chemical and physical characterization of analcime is satisfactory making the experimental protocol very promising for an industrial transfer.

The structure of zeolites consists of three-dimensional frameworks of $\mathrm{SiO}_{4}$ and $\mathrm{AlO}_{4}$ tetrahedra arranged to form channels containing water and exchangeable cations (sodium, potassium, calcium etc.). Analcime (ANA) zeolite is the smallest-pore zeolite, and it exhibits a compact structure compared to other zeolites with an idealized unit cell of $\mathrm{Na}_{16} \mathrm{Al}_{16} \mathrm{Si}_{32} \mathrm{O}_{96} \cdot 16 \mathrm{H}_{2} \mathrm{O}^{1}$; its complex structure, build of corner sharing $\left[\mathrm{SiO}_{4}\right]$ and $\left[\mathrm{AlO}_{4}\right]$ tetrahedron, creates irregular channels and some cavities occupied by the exchangeable Na-ions in the crystal lattice ${ }^{2}$. Analcime is usually of cubic singony, space group I $3 d^{3-6}$. Saha ${ }^{6}$ described the cubic unit cell composed of four-, six-, and eight-membered oxygen rings forming three non-intersecting channels. Every sodium ion is surrounded by four oxygens ions and two water molecules, which make up a distorted octahedron ${ }^{7}$. Yokomori and Idaka ${ }^{8}$ report that every pseudocubic or average cubic analcime is really trigonal (R-3). Orthorombic natural analcime is also reported ${ }^{9}$. Analcime occurs in various geological environments. Type $\mathrm{H}$ analcime is formed under hydrothermal conditions by dissolution of source materials such as nepheline, plagioclase, albite, quartz, volcanic glass and recrystallization from hydrothermal solutions. A particular case of Analcime which is formed under hydrothermal conditions is that which is formed by cationic exchange $\mathrm{K}-\mathrm{Na}$ from Leucite ${ }^{10}$; this analcime is called X type Analcime. Morphologically it retains the leucite habit, but it is dusty and often the crystal core is still leucite ${ }^{11}$. This cation exchange reaction requires 3 days at $300^{\circ} \mathrm{C}$ and $1 \mathrm{Kbar}$ and the use of Leucite crystals of at least 100 microns size, as well as an activation energy of $8 \mathrm{kcal} / \mathrm{mol}^{12}$. The thermal ${ }^{11}$ and morphological ${ }^{13}$ analyses allow to distinguish the type of analcime ( $\mathrm{H}$ or $\mathrm{X})$. Then there is the I type analcime which segregates itself directly from the magma and occurs inside igneous rocks ${ }^{14}$.

Analcime exhibits a variety of applications in technology, especially in selective adsorption in waste water treatments ${ }^{15-18}$ and heterogeneous catalysis ${ }^{19-21}$; in particular, the incorporation of transition elements $(\mathrm{Fe}, \mathrm{Co}, \mathrm{Ni}$,

${ }^{1}$ Dipartimento di Ingegneria e Geologia, Università Degli Studi "G.D'Annunzio", Via dei Vestini 30, 66013 Chieti, Italy. ${ }^{2}$ Dept. Mineralogia, Petrologia I Geologia Aplicada, Universitat de Barcelona, 08028 Barcelona, Spain. ${ }^{\square}$ email: daniela.novembre@unich.it 
$\mathrm{Cu}, \mathrm{Ti}$ and $\mathrm{V}$ ) in the zeolite framework, or in the porous system as compensating cations, allows to create diverse catalytic sites ${ }^{22,23}$. Analcime is also successfully used as fertilizer dispenser in agriculture ${ }^{15}$, in the nanoelectronic field ${ }^{24}$, in stomatology, i.e. in ceramics for denture ${ }^{25,26}$.

Even if Analcime is found in nature, abundant supplies of this mineral occur in limited regions of the world. For this reason, recent research is moving towards the synthesis of this mineral by using different sources of silica and alumina.

Usually, analcime is synthesized under hydrothermal conditions using aluminosilicate clear solutions or gels, in the presence of an alkaline medium and at temperature variable from 100 to $310^{\circ} \mathrm{C}$. Some studies demonstrates that the more $\mathrm{Na}_{2} \mathrm{O}$ is in the initial raw materials, the lower the temperature at which analcime crystallizes ${ }^{27}$. The alternative route is to synthesize analcime from cheap local materials, i.e. by the conversion of natural glasses ${ }^{28}$, conformed ashes $^{29}$, rhyolitic tuff ${ }^{30}$, rice husk ${ }^{31-35}$, rice husk and perlite ${ }^{36}$, clinker ${ }^{37}$, quartz syenite powders ${ }^{38}$, $\mathrm{k}$-felspar ${ }^{39}$ and clays $\mathrm{s}^{22,40,41}$ which represent highly reactive raw materials. However not only analcime prevails among the reached synthesis ${ }^{42}$.

As regards the use of clays, kaolin is the material already tested in the synthesis of analcime. Among clay minerals, in fact, kaolinite is the most used phyllosilicate in the zeolitic synthesis because of its particularly large supply and availability and the well-known activity of thermally treated kaolin clays (metakaolin) when treated with alkali-based reagents ${ }^{43-49}$. Rios et al. ${ }^{50}$ treated kaolinite with $\mathrm{NaOH}$ and obtained co-crystallization of analcime and other zeolites; Hegazy et al. ${ }^{22}$ synthesized analcime by hydrothermal reaction of kaolin and commercial sodium silicate solution at $200^{\circ} \mathrm{C}$ for $24 \mathrm{~h}$ under autogenous pressure; Atta et al. ${ }^{40}$ synthesized analcime from kaolin after $72 \mathrm{~h}$ aging and $24 \mathrm{~h}$ reaction time at temperature of $180^{\circ} \mathrm{C}$; Jamil et al.$^{41}$ mixed Kaolinite, Ludox 40 and $\mathrm{NaOH}$ and get analcime after $30 \mathrm{~min}$ at $160^{\circ} \mathrm{C}$ in a microwave system; Moraes et al. ${ }^{51}$ treated calcined kaolin and diatomaceous earth with $\mathrm{NaOH}$ at $210^{\circ} \mathrm{C}$ for $24 \mathrm{~h}$ and obtained analcime with minor amounts or residual quartz; Kwaky-Awuah et al. ${ }^{52}$ synthesized powders of LTA, analcime and X zeolite starting from Kaolin and bauxite; Ramirez-Zamora et al. ${ }^{33}$ synthesized polimineralic powders of analcime by fly ash and kaolinite; Abdul-Moneim et al. ${ }^{53}$ treated kaolin with $\mathrm{NaOH}$ at $170{ }^{\circ} \mathrm{C}$ for $36 \mathrm{~h}$ and obtained co-crystallizations of analcime, cancrinite and sodalite.

As is evident from the results of the previous attempts aimed at the synthesis of the analcime starting from kaolin, one of the fundamental problems is not being able to synthesize monomineral powders of analcime; the mineral is, in fact, often present as an accessory in the synthesis of other zeolites, or in coexistence with phases associated to the starting material ${ }^{51}$. This fact (not to obtain monomineralic products) is the same that prevents extensive use of natural analcime. The coexistence in the synthesis powders of analcime with other mineralogical phases has made its characterization difficult up to now, limiting this only to morphological and X-ray diffractometric observations. In few cases ${ }^{22,40,41}$ authors declare to obtain monomineralic powders of analcime, but it must also be said that none of them has actually conducted a study aimed at characterizing the purity of the synthetic product, i.e. at investigating the possible presence of unreacted and/or amorphous material. The lack of these data prevents an industrial transfer of the synthesis protocols; industry requires at least $90 \%$ pure synthesis powders.

Given the situation, the purpose of this work is to synthesize analcime by testing a natural rock, i.e. a kaolinitic rock coming from Romana (Italy). This kaolin has already been successfully used in the past in the synthesis of useful minerals ${ }^{47-49}$. Romana kaolin has the advantage of being characterized by an excess of silica compared to common commercial kaolin, being its mineralogical composition made of kaolinite plus minor amounts of quartz and opal-crystobalite ${ }^{47}$. This peculiar characteristic gives the material a Si/Al ratio greater than 1 and it makes it suitable for the synthesis of minerals characterized by and $\mathrm{Si} / \mathrm{Al}$ ratio higher than 1:1, like analcime. Because of this, the use of Romana kaolin avoids the addition of sodium silicate or other silica sources, and it makes the synthesis protocol simpler and above all cheaper than in the past.

In particular, this work aims to improve the previous attempts made in the past for the synthesis of the analcime from kaolin by avoiding co-crystallization of mineral phases, aging times and by lowering: (1) synthesis temperature (2) crystallization time and (3) kaolin calcination temperature. Systematic samplings during the experimental run enable to follow the progress in the crystallization of the mineral phases and allows to determine the time at which the climax in the crystallization is reached. The degree of purity of the synthesized powders expressed in terms of absence of amorphous phase and/or impurities coming from the natural kaolinite sample is here defined through a quantitative phase analysis approach using the combined Rietveld and reference intensity ratio methods.

\section{Materials and methods}

The kaolin used in this study comes from a mine loca ted in Romana (Sassari, Italy). For the chemical composition of kaolin and its mineralogical, morphological and spectroscopic characterization, see Novembre et al. ${ }^{47}$. The kaolin was triturated, and the sandy fraction was separated by retention in a sieve; then the fraction below $90 \mu \mathrm{m}$ was collected, suspended in distilled water, sonicated, and centrifuged for separation of the silt fraction and collection of the clay fraction ${ }^{49}$. Preliminary calcination of kaolin was carried out in open porcelain crucibles heated in a Gefran Model 1200 furnace (Gefran Spa, Brescia, Italy) to the calcination temperature $\left(650^{\circ} \mathrm{C}\right)$ at a pressure of $1 \mathrm{~atm}$. The heating rate of the sample was $1.5^{\circ} \mathrm{C} \mathrm{s}^{-1}$. Once the calcination temperature was reached, the crucibles were left in the furnace for $2 \mathrm{~h}$ and then removed and cooled at room temperature. The $\mathrm{NaOH}$ used in the synthesis protocol was purchased from Riedel-de Haën (Honeywell Riedel-de Haën, Bucharest, Romania). The purity of the reagent was of $99 \%$. As explained above, kaolin of Romana is characterized by an excess of silica compared to the common stoichiometry of commercial kaolin ${ }^{47}$, and do not require addition of sodium-silicate. $2 \mathrm{~g}$ of metakaolinite have been directly dissolved in $20 \mathrm{ml}$ of a $\mathrm{NaOH}(8 \%)$ solution. The initial mixture had the composition: $6.25 \mathrm{SiO}_{2}-1.00 \mathrm{Al}_{2} \mathrm{O}_{3}-3.6 \mathrm{Na}_{2} \mathrm{O}$. The mixture was homogenized for two hours with a magnetic stirrer. Then it was put inside a stainless-steel hydrothermal reactor and heated at $10{ }^{\circ} \mathrm{C} / \mathrm{min}$ 


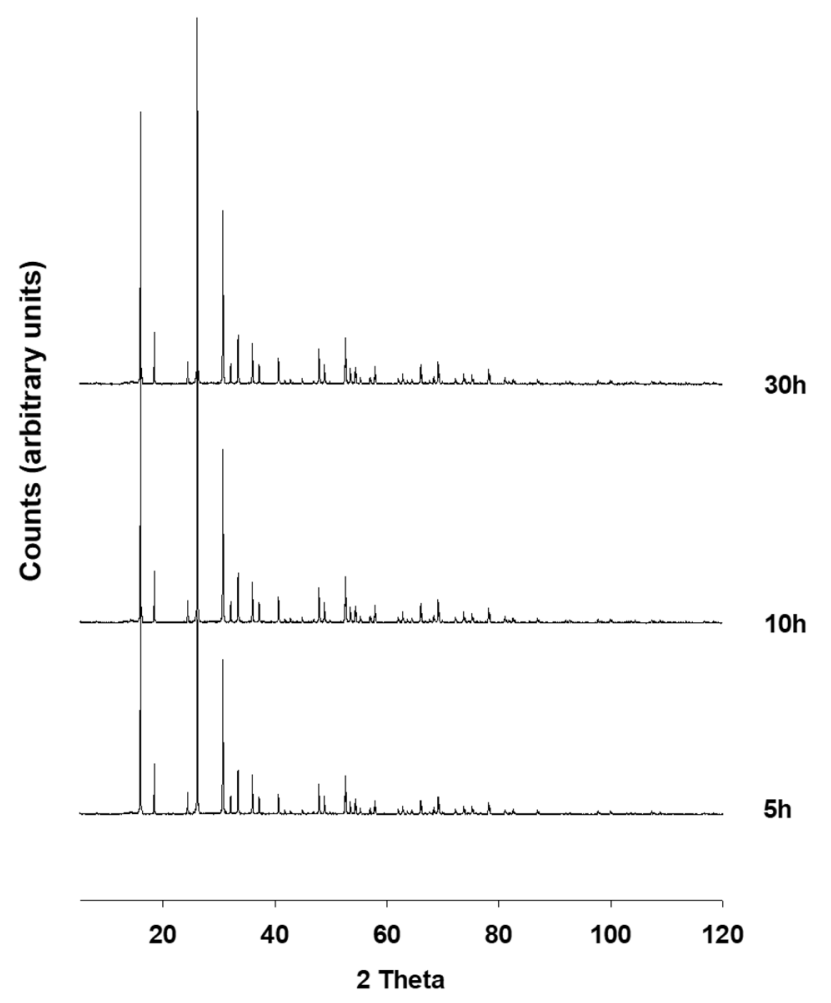

Figure 1. X-ray diffractometric sequence of the synthesis run at $170{ }^{\circ} \mathrm{C}$.

until the desired temperature $\left(170^{\circ} \mathrm{C}\right)$. Synthesis products were sampled periodically from the reactor, filtered with distilled water and dried in an oven at $40{ }^{\circ} \mathrm{C}$ for a day.

Kaolin and products of synthesis were analyzed by powder X-ray diffraction (XRPD); the instrument was a Siemens D5000 operating with a Bragg-Brentano geometry $\left(\mathrm{CuKa}=1.518 \AA, 40 \mathrm{kV}, 40 \mathrm{~mA}, 4^{\circ}-120^{\circ} 2\right.$ theta scanning interval, step size $0.020^{\circ}$ theta). Identification of analcime and relative peak assignment was performed with reference to the following JCPDS code: 00-019-1180. Both the crystalline and amorphous phases in the synthesis powders were estimated using quantitative phase analysis (QPA) applying the combined Rietveld and reference intensity ratio (RIR) methods; corundum NIST 676a was added to each sample, amounting to 10\% (according to the strategy proposed by Novembre et al. ${ }^{47,49}$ and the powder mixtures were homogenized by hand-grinding in an agate mortar. Data for the QPA refinement were collected in the angular range $5^{\circ}-110^{\circ} 2$ theta with steps of $0.02^{\circ}$ and $10 \mathrm{~s} \mathrm{step}^{-1}$, a divergence slit of $0.5^{\circ}$ and a receiving slit of $0.1 \mathrm{~mm}$.

Data were processed with the GSAS software ${ }^{54}$ and the graphical interface ${ }^{55}$ starting with the structural model proposed by Gatta et al. ${ }^{56}$ for analcime. The following parameters were refined: background parameters, zero shift, cell parameters and peak profiles.

Morphological analyses were obtained by means of scanning electron microscopy (JEOL JSM-840 served by a LINK Microanalysis EDS system, with operating conditions of $15 \mathrm{kV}$ and window conditions ranging from 18 to $22 \mathrm{~mm})^{57}$.

Induced coupled plasma optical emission spectroscopy technique (ICP-OES, Perkin Elmer Optima 3200 RL) was performed on synthesized powders through previous fusion (Pt meltpot) in lithium meta-tetra borate pearls and subsequent acid solubilisation and analytical determination ${ }^{58}$.

Density of Analcime was calculated by He-picnometry using an AccuPyc 1330 pycnometer $^{59}$.

The infrared analysis was performed with a spectrometer FTLA2000, served by a separator of $\mathrm{KBr}$ and a DTGS detector; the source of IR radiation was a SiC (Globar) filament. Samples were treated according to the method of Novembre et al. ${ }^{60}$ using powder pressed pellets $(\mathrm{KBr} /$ sample ratio of $1 / 100$, pressure undergone prior determination $15 \mathrm{t} / \mathrm{cm}^{2}$ ); spectra were processed with the program GRAMS-Al (GRAMS/AI ${ }^{\mathrm{Tx}}$ Spectroscopy Software, Thermo Scientific Company).

Differential thermal analysis (DTA) and thermogravimetry (TG) were performed using a Mettler TGA/ SDTA851e instrument $\left(10^{\circ} \mathrm{min}, 30-1100^{\circ} \mathrm{C}\right.$, sample mass of $\sim 10 \mathrm{mg}, \mathrm{Al}_{2} \mathrm{O}_{3}$ crucible) (Mettler Toledo, Greifensee, Switzerland).

\section{Results}

Results of XRPD analyses performed on the synthesis run conducted at $170^{\circ}$ are illustrated in Fig. 1.

Synthesis of analcime is evident at $5 \mathrm{~h}$. The existence field of the ANA zeolite is very large, in fact the phase remains isolated for a long time; peaks grow in height until reaching the maximum intensity at $10 \mathrm{~h}$. The intensity of the peaks remains unchanged even at $30 \mathrm{~h}$, proving that the climax of crystallization is reached only $10 \mathrm{~h}$ after the start of the thermal treatment. Results of the QPA analyses conducted on samples at 5, 10 and $30 \mathrm{~h}$ are 


\begin{tabular}{|l|l|l|l|}
\hline Sample $+\mathbf{1 0} \%$ corundum Nist 676a & $\mathbf{5} \mathbf{h}$ & $\mathbf{1 0} \mathbf{h}$ & $\mathbf{3 0} \mathbf{~}$ \\
\hline $\mathrm{R}_{\text {wp }}$ & 0.19 & 0.18 & 0.18 \\
\hline $\mathrm{R}_{\mathrm{p}}$ & 0.14 & 0.15 & 0.14 \\
\hline $\mathrm{CHI}^{2}$ & 2.08 & 2.18 & 2.17 \\
\hline Space group ANA & $\mathrm{Ia}-3 d$ & $\mathrm{I} a-3 d$ & $I a-3 d$ \\
\hline$a(\AA)$ & $14.2071(0.0051)$ & $14.2041(0.0037)$ & $14.2052(0.0035)$ \\
\hline$b(\AA)$ & $10.0515(0.0005)$ & $10.0536(0.0018)$ & $10.0539(0.0021)$ \\
\hline$c(\AA)$ & $10.0418(0.0007)$ & $10.0427(0.0004)$ & $10.0416(0.0006)$ \\
\hline$\%$ amorphous & $6.53(13)$ & $2.43(11)$ & $2.47(11)$ \\
\hline ANA & $93.47(17)$ & $97.57(14)$ & $97.53(14)$ \\
\hline
\end{tabular}

Table 1. Results of the QPA analyses conducted on samples synthesized at $170{ }^{\circ} \mathrm{C}$.



Figure 2. Rietveld refinement plot: Observed $(+)$ and calculated profiles and difference plot for analcime zeolite $\left(10 \mathrm{~h}\right.$ at $\left.170^{\circ} \mathrm{C}\right)$ and corundum NIST $676 \mathrm{a}$ with tick marks at the position of the Bragg peaks. From the bottom: analcime zeolite, corundum NIST 676a.

illustrated in Table 1. Analcime percentage increases over time at the expense of the amorphous component and reaches its climax at $10 \mathrm{~h}(97.57 \%)$. There is no substantial change in the percentages of the crystalline fraction versus the amorphous one passing from 10 to $30 \mathrm{~h}$. It must be said that the nature of the silica source used in the synthesis and the impurities present in it are reported to have a significant effect on the purity of the final products $^{61,62}$. This is certainly the major limitation found in mineral synthesis procedures starting from georesources. In the particular case of analcime synthesis, Navickas et al. ${ }^{42}$ report that the amount of analcime in the synthesis products depends on the nature of the raw materials and Atta et al. ${ }^{40}$ report metallic impurities coming from the rice husk and kaolinite used as starting material in the synthesis protocol. The QPA analysis allows to exclude the presence of accessory mineralogical phases and / or impurities coming from the starting kaolinite.

For the sample at $10 \mathrm{~h}$ the observed and calculated profiles and difference plots for analcime and corundum NIST 676a are reported in Fig. 2. Cell parameters of analcime, refined with cubic simmetry space group Ia-3d, 

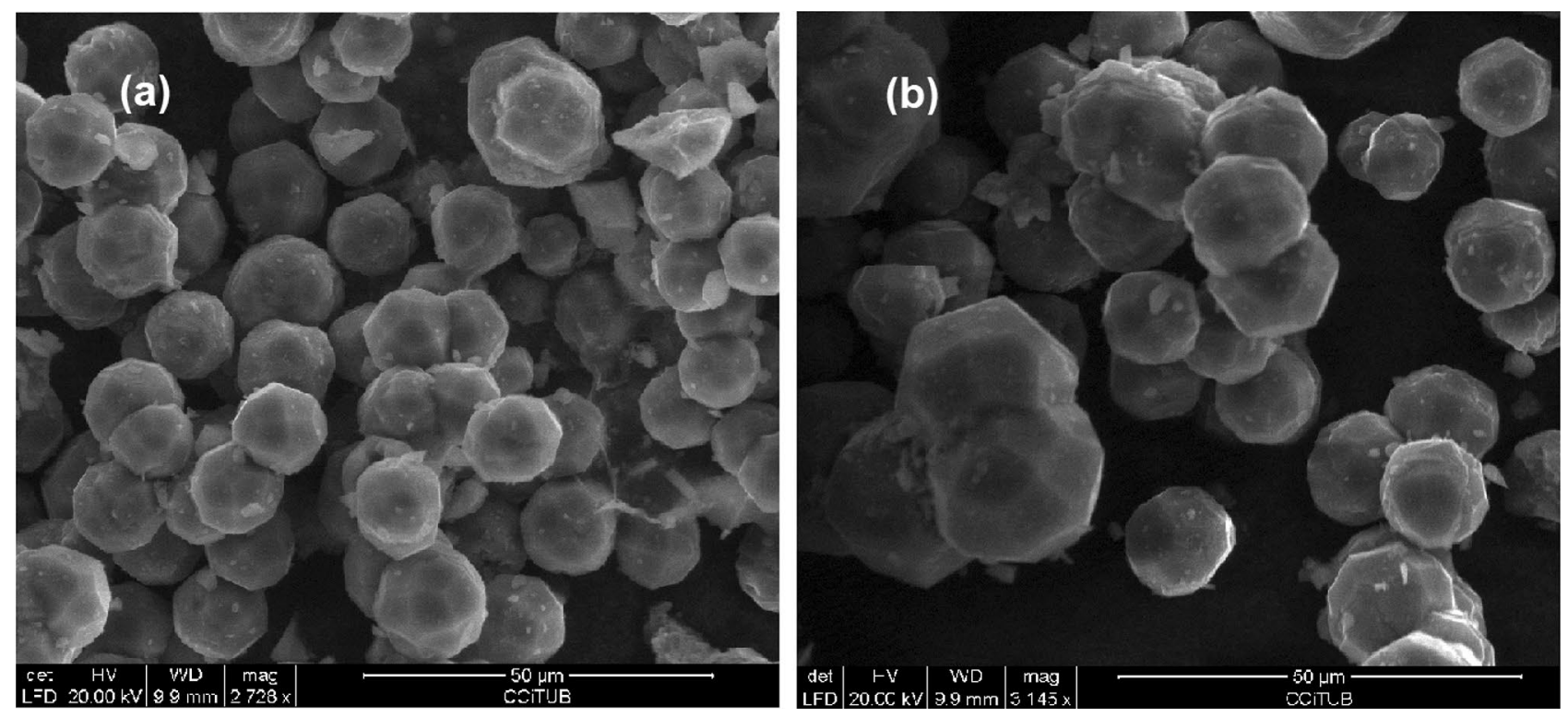

Figure 3. SEM images of analcime zeolite crystals obtained at $5 \mathrm{~h} \mathrm{(a)}$ and at $10 \mathrm{~h}(\mathbf{b})$ of the synthesis run.

remain constant within error as a function of the experimental run time. The results of the Rietveld refinements provide cell values that are in good agreement with the structural model proposed by Gatta et al. ${ }^{56}$.

Figure $3 \mathrm{a}$ and $\mathrm{b}$ reports SEM images of analcime crystals at $5 \mathrm{~h}$ and $10 \mathrm{~h}$, respectively. It results an average maximum length of crystals observed to be around $25 \mu \mathrm{m}$. This result is very satisfying when compared with the size of the crystals obtained by other authors in the past. As an example, Jamil et al. ${ }^{41}$, synthesize analcime from kaolinite reaching crystal sizes of 5-7 $\mu \mathrm{m}$, while Hegazy et al. ${ }^{22}$ testify average dimensions of $10 \mu \mathrm{m}$. Chemical analysis performed on samples at $10 \mathrm{~h}\left(170^{\circ} \mathrm{C}\right)$ resulted in the stoichiometry of $\mathrm{Na}_{6.00} \mathrm{Al}_{5.98} \mathrm{Si}_{12.02} \mathrm{O}_{36}$. The density of analcime from the sample at $10 \mathrm{~h}\left(170^{\circ} \mathrm{C}\right)$ was determined to be $2.261(5) \mathrm{g} / \mathrm{cm}^{3}$.

Further characterizations were carried out on the sample at $10 \mathrm{~h}\left(170^{\circ} \mathrm{C}\right)$. Figure 4 illustrates the infrared spectrum of the sample. Information on the structure of the mineral can be inferred from the vibrational frequencies of the lattice observed in the range between 4000 and $400 \mathrm{~cm}^{-1}$. Data reported in Fig. 4 are coherent with those available in the literature $e^{24,40,63}$. The significant broad peaks are located at 3467 and $1638 \mathrm{~cm}^{-1}$ for $\mathrm{O}-\mathrm{H}$ stretching and bending, respectively. In particular, the band at $3467 \mathrm{~cm}^{-1}$ is associated to the asymmetric stretching mode of water coordinated to the edges of the channels, while the band at $1638 \mathrm{~cm}^{-1}$ is assigned to the zeolitic water in the channels of zeolite ${ }^{64}$. The bands at 1029 and $1091 \mathrm{~cm}^{-1}$ are attributed to the stretching mode of $\mathrm{O}-\mathrm{Na}-\mathrm{O}$. The bands at 768, 742, 698 and $625 \mathrm{~cm}^{-1}$ are attributed to $\mathrm{Si}-\mathrm{O}-\mathrm{Si}$ symmetric stretching vibration, i.e. to the symmetric stretching vibration of 4 -membered rings. Abdul-Monheim et al. ${ }^{53}$ noticed that these bands occur at relatively high wave numbers in the pseudo lattice band range as these rings contain the lowest number of all rings occurring in the zeolite structure. Bands at 446 and $416 \mathrm{~cm}^{-1}$ are characteristic of of $\mathrm{O}-\mathrm{Si}-\mathrm{O}$ bonding mode, i.e. to the typical bending vibrations of 4 -membered rings.

Thermogravimetric analysis conducted on samples at $10 \mathrm{~h}\left(170^{\circ} \mathrm{C}\right)$ revealed a gradual and continuous water loss up to $1000^{\circ} \mathrm{C}$ (Fig. 5). In particular three well defined dehydration steps are observed at 140,415 and $980^{\circ} \mathrm{C}$. This three step-dehydration process here observed is in agreement with findings by Sandoval et al. ${ }^{37}$. The position and number of peaks can be attributed to different compensating cation-water binding energies and also to the different energy related to the diffusion of desorbed water ${ }^{53}$. Moreover, the amount of desorbed water is related with the number of compensation cations in the framework of the zeolite ${ }^{65}$. In particular, the first two observed peaks in Fig. 5 correspond to removal of physical absorbed and occluded water. The loss at $980{ }^{\circ} \mathrm{C}$ is due to gradual removal of water in micropores. A total weight loss of $13.5 \%$ is obtained, in agreement with data of Sandoval et al. ${ }^{37}$ and Hegazy et al. ${ }^{22}$.

\section{Conclusion}

A goal of fundamental importance that research today seeks to pursue is the green synthesis of minerals achieved by using naturally derived reagents. At the same time, research seeks to reduce synthesis time and temperature to create inexpensive protocols from an economic point of view. This work describes the synthesis of analcime using a kaolinitic rock coming from Romana (Sassari, Italy). Analcime has already been synthesized in the past from kaolin $^{22,33,40,41,51-53,65}$. One of the fundamental problems identified in the attempts to synthesize analcime starting from kaolinite is the enormous difficulty of obtaining the mineral isolated from other phases. Only in a few cases some authors report having synthesized monomineral powders of analcime ${ }^{22,40,41}$. When our results are compared with the past literature, a reduction of calcination temperature of kaolinite, of the synthesis temperature, and of crystallization time is evident. Furthermore, no aging time is required in the synthesis protocol. In addition, our protocol does not require for the use of sodium silicate or other silica sources ${ }^{41}$. Romana kaolin is characterized by an excess of silica compared to pure $\operatorname{kaolin}^{47}$; this makes the experimental procedure cheaper and faster. 


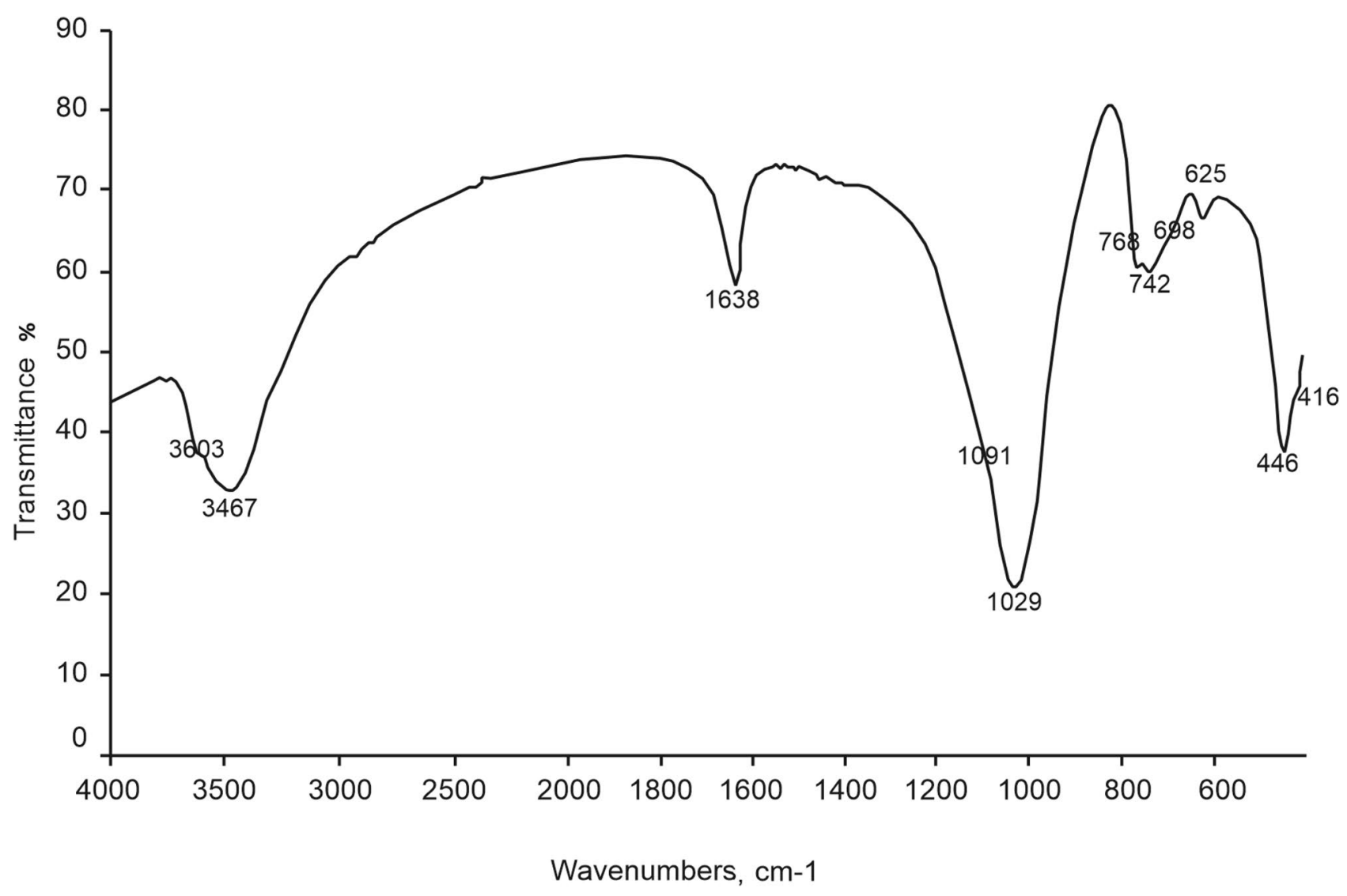

Figure 4. IR spectrum of the analcime at $10 \mathrm{~h}\left(170^{\circ} \mathrm{C}\right)$.

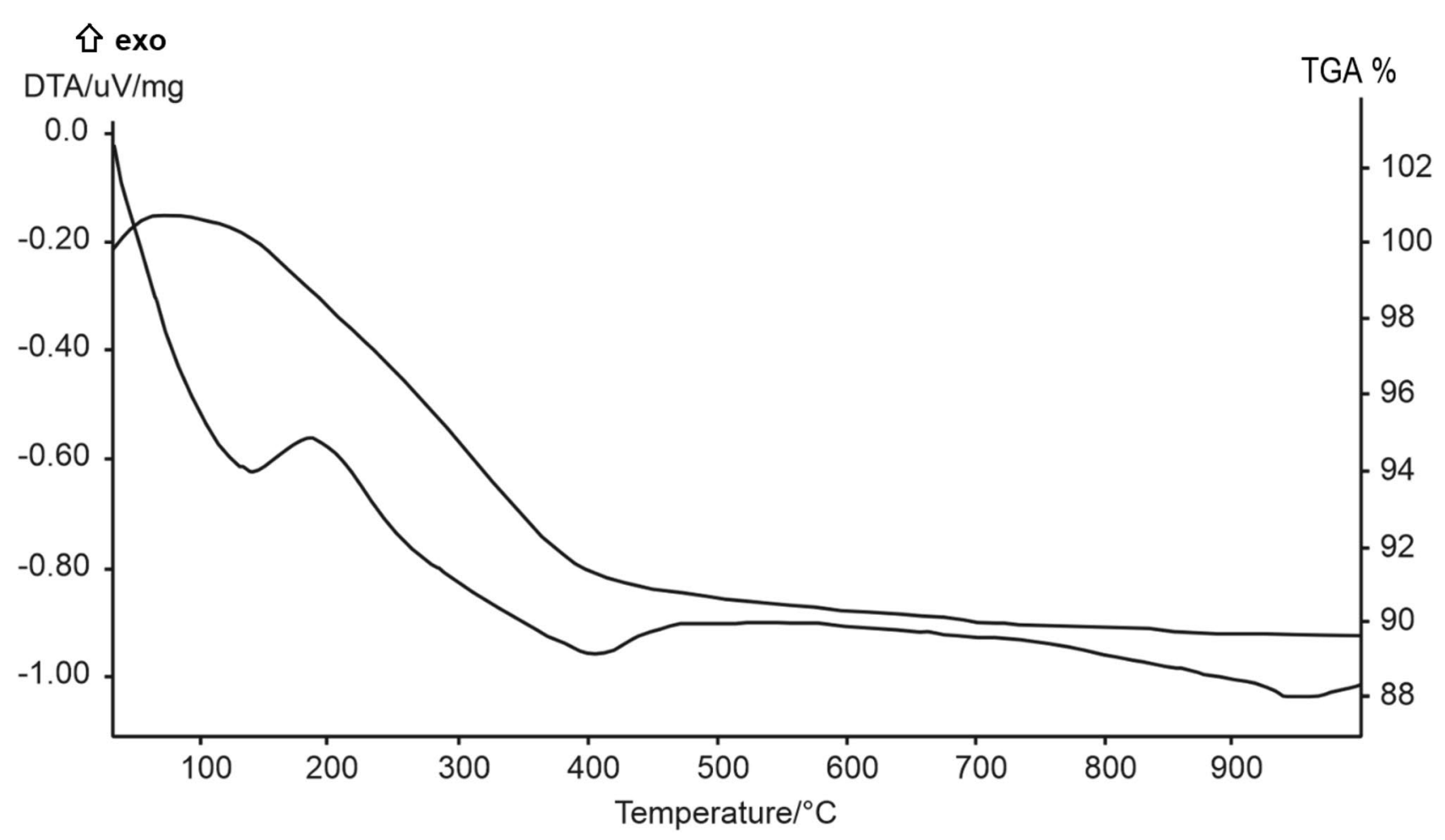

Figure 5. DTA-TG analysis of the sample at $10 \mathrm{~h}\left(170^{\circ} \mathrm{C}\right)$. 
Hegazy et al..$^{22}$ operate a calcination temperature of kaolinite of $900{ }^{\circ} \mathrm{C}$, while we reduced it to $650{ }^{\circ} \mathrm{C}$.

Hegazy a et al..$^{22}$ got analcime at $24 \mathrm{~h}$ at $200^{\circ} \mathrm{C}$, and Atta et al. ${ }^{40}$ got Analcime after $72 \mathrm{~h}$ aging and $24 \mathrm{~h}$ reaction time at $180^{\circ} \mathrm{C}$; in our work ANA zeolite crystallizes at only $5 \mathrm{~h}$ at $170{ }^{\circ} \mathrm{C}$. In our case the existence field of the zeolite is very large, in fact no phase replaces it in the time interval 5-30 h. The dimensions of the crystals obtained are larger when compared with previous authors ${ }^{22,40}$ and also greater than those obtained by the microwave synthesis method ${ }^{41}$, in spite that this is a more performing method that considerably reduces the time and crystallization temperatures $\left(30 \mathrm{~min}\right.$ at $\left.160^{\circ} \mathrm{C}\right)$.

In mineralogical synthesis processes in general, but when synthesizing starting from natural reagents in particular, great attention must be paid to characterizing the degree of purity of the synthetic products. In fact, amorphous residues or even impurities of the starting material can often be present in the final ones, or even results in the desired phase is not isolated, but in coexistence with others. Industry requires at least $90 \%$ purity. It must be said that as far as we know none of the authors in the past has estimated the degree of purity of the synthetic powders. In our opinion, from this it is not possible to establish whether these are representative of the climax of crystallization, or to exclude the presence of minor other phases and/or amorphous residues.

The degree of success of an experiment is here established from calculation of the percentage of crystallization $v s$. amorphous material and other impurities. In our case, already at $5 \mathrm{~h}$ of the synthesis run, $93.47 \%$ is reached, which is already a sufficient achievement for the parameters required by industry. Then at $10 \mathrm{~h}$ it exceeds $97 \%$. This percentage remains unchanged for a long time, therefore the stability range of the mineral is wider than that obtained by the previous authors in the literature. All other characterization, i.e. chemical-physical, morphologi$\mathrm{cal}$, and spectroscopic characterization of experimental products testifies the efficacy of the experimental protocol proposed here. All these results suggest that transfer to an industrial production scale would be easily possible.

Last but not least, this work does not use a commercial kaolin but a kaolinite rock from a disused quarry. This further reduces the costs of the experimental protocol. It also gives the protocol an added value, as the synthesis of a useful mineral is obtained through the enhancement of an otherwise unused georesource. In addition, as Romana's kaolin is characterized by an excess of silica with respect to commercial kaolin, this study opens the way to the use of so-called "impure" kaolins and demonstrates that are a better natural product (till now rejected in most of cases, and therefore, cheaper) in the synthesis processes of useful minerals characterized by a $\mathrm{Si} / \mathrm{Al}$ ratio higher that $1: 1$.

Received: 19 April 2021; Accepted: 14 June 2021

Published online: 28 June 2021

\section{References}

1. Meier, W. M. \& Olson, D. H. Atlas of Zeolite Structure Types 4th edn, 405 (Elsevier Science, 1996).

2. Baerlocher, C., McCusker, L. B. \& Olson, D. H. Atlas of Zeolite Framework Types (Elsevier, 2001).

3. Calleri, M. \& Ferraris, G. Ricerche cristallografico-strutturali sull'analcime: $\mathrm{NaAlSi}_{2} \mathrm{O}_{6} \cdot \mathrm{H}_{2} \mathrm{O}$. Atti Accad. Sci. 98, 821-846 (1964).

4. Knowles, C. R., Rinaldi, F. F. \& Smith, J. V. Refinement of the crystal structure of analcime. Indian Mineral. 6, 127-140 (1965).

5. Ferraris, G., Jines, D. W. \& Yerkess, J. A neutron-diffraction study of the crystal structure of Analcime, $\mathrm{NaAlSi}_{2} \mathrm{O}_{6} \cdot \mathrm{H}_{2} \mathrm{O} . \mathrm{Z} . \mathrm{Crystal}$ logr. 135, 240-252 (1972).

6. Saha, P. Geochemical and X-ray investigation of natural and synthetic analcites. Am. Mineral. 44, 300 (1959).

7. Palubinskaite, D., Sinkeviciene, I., Siauciunas, R. \& Sadunas, A. Determination of the parameters of Analcime synthesis and the obtaining of Leucite by ion exchange. Mater. Sci. 6(1), 36-43 (2000).

8. Yokomori, Y. \& Idaka, S. The crystal structure of Analcime. Microporous Mesoporous Mater. 21, 365-370 (1998).

9. Pechar, F. An X-ray diffraction refinement of the crystal structure of natural orthorhombic analcime $\left(\mathrm{NaAlSi}_{2} \mathrm{O}_{6} \cdot \mathrm{H}_{2} \mathrm{O}\right) . \mathrm{Zeolites} \mathbf{8}$, 247-249 (1988).

10. Karlsson, H. R. \& Clayton, R. N. Oxygen and hydrogen isotope geochemistry of zeolites. Geochem. Cosmochim. Acta 54, 1369-1386 (1990).

11. Giampaolo, C. \& Lombardi, G. Thermal behaviour of analcimes from two different genetic environment. Eur. J. Mineral. 6, 285-289 (1994).

12. Gupta, A. K. \& Fyfe, W. S. Leucite survival: The alteration to analcime. Can. Mineral. 13, 361-363 (1975).

13. Putnis, A., Putnis, C. \& Giampaolo, C. The microtexture of analcime phenocrysts in igneous rocks. Eur. J. Mineral. 6, 627-632 (1994).

14. Karlsson, H. R. \& Clayton, R. N. Analcime phenocrysts in igneous rocks: Primary or secondary?. Am. Mineral. 76, 189-199 (1991).

15. Dyer, A., Tangkawanit, S. \& Rangsriwatananon, K. Exchange diffusion of $\mathrm{Cu}^{2+}, \mathrm{Ni}^{2+}, \mathrm{Pb}^{2+}$ and $\mathrm{Zn}^{2+}$ into analcime synthesized from perlite. Microporous Mesoporous Mater. 75(3), 273-279 (2004).

16. Tangkawanit, S., Rangsriwatananon, K. \& Dyer, A. Ion exchange of $\mathrm{Cu}^{2+}, \mathrm{Ni}^{2+}, \mathrm{Pb}^{2+}$ and $\mathrm{Zn}^{2+}$ in analcime (ANA) synthesized from Thai perlite. Microporous Mesoporous Mater. 79, 171-175 (2005).

17. Mallah, M. H., Soorchi, H. \& Jooybari, T. F. Development of empirical equation for analcime in the treatment of nuclear waste. Ann. Nucl. Energy 47, 140-145 (2012).

18. Zhang, Y., Jing, Z., Kameda, T. \& Yoshioka, T. Hydrothermal synthesis of hardened diatomite-based adsorbents with analcime formation fot methylene blue adsorption. RSC Adv. 6(32), 26765-26774 (2016).

19. Tatlier, M., Baris Cigizoglu, K., Tokay, B. \& Erdem-Senatalar, A. Microwave vs. conventional synthesis of analcime from clear solutions. J. Cryst. Growth 306, 146-151 (2007).

20. Azizi, S. N. \& Tilami, S. E. Framework-incorporated Mn and Co analcime zeolites: Synthesis and characterization. Microporous Mesoporous Mater. 167, 89-93 (2013).

21. Bejar, A., Chaabene, S. B., Jaber, M., Lambert, J. F. \& Bergaoui, L. Mn-analcime: Synthesis, characterization and application to cyclohexene oxidation. Microporous Mesoporous Mater. 196, 158-164 (2014).

22. Hegazy, E. Z., Abd El Maksod, I. H. \& Abo El Enin, R. M. M. Preparation and characterization of Ti and V modified analcime from local kaolin. Appl. Clay Sci. 49, 149-155 (2010).

23. Bell, A. M. T. \& Henderson, C. M. B. Rietveld refinement of dry-synthesized $\mathrm{Rb}_{2} \mathrm{ZnSi}_{5} \mathrm{O}_{12}$ leucite by synchrotron X-ray powder diffraction. Acta Cryst. C52, 490 (1996).

24. Liu, B. S., Tang, D. C. \& Au, C. T. Fabrication of analcime zeolite fibers by hydrothermal synthesis. Microp. Mesop. Mat. 86, 106-111 (2005).

25. Balandis, A. \& Traidaraite, A. The influence of Al containing component on synthesis of analcime of various crystallographic systems. Mater. Sci. Pol. 25, 637-647 (2007). 
26. Rasmussen, S. T., Groh, C. L. \& O’Brien, W. J. Stress induced phase transformation of a cesium stabilized leucite porcelain and associated properties. Dent. Mater. 14, 202-211 (1998).

27. Breck, D. W. Zeolite Molecular Sieves. Structure, Chemistry and Use 771 (Robert E. Krieger Publishing Company, Malabar, 1984).

28. Derkowski, A. Experimental transformation of volcanic glass from Streda nad Bodrogom (SE Slovakia). Geol Carpath 2002, vol. 53. In Proceedings of the XVII Congress of Carpathian-Balkan Geological Association Bratislava (2002).

29. Garcia, J., Cazorla, D. \& Linares, A. Selective synthesis of zeolite briquettes from conformed ashes. J. Chem. Tech. Biot. 77, 287-291 (2002).

30. Abe, H., Aoki, M. \& Konno, H. Synthesis of analcime from volcanic sediments in sodium silicate solution. Contrib. Miner. Petr. 42, 81-92 (1973).

31. Petkowicz, D. I., Rigo, R. T., Radtke, C., Pergher, S. B. \& dos Santos, J. H. Z. Zeolite NaA from Brazilian chrysotile and rice husk. Microporous Mesoporous Mater. 116, 548-554 (2008).

32. Azizi, S. N. \& Ypusefpour, M. Synthesis of zeolites NaA and analcime using rice husk ash as silica source without using organic template. J. Mat. Sci. 45, 5692-5697 (2010).

33. Ramirez-Zamora, R. M., Solis-Lopez, M., Robles-Gutierrez, I., Reyes-Vidal, Y. \& Espejel-Ayala, F. A statistical industrial approach for the synthesis conditions of zeolites using fly ash and kaolinite. Environ. Progr. Sustain. 37(1), 310-332 (2017).

34. Querol, X. et al. Synthesis of zeolites from coal fly ash: an oveview. Int. J. Coal Geol. 50, 413-423 (2002).

35. Sanhueza, V. M. \& Bennun Torres, L. D. Synthesis of zeolitic materials from volcanic ash in presence and absence of cetyltrimethylammonium bromide. Rev. Int. Contam. Ambie. 31(2), 185-193 (2015).

36. Kongkachuichay, P. \& Lohsoontorn, P. Phase diagram of zeolite synthesized from perlite and rice husk ash. Sci. Asia 32, 13-16 (2006).

37. Sandoval, M. V., Henao, J. A., Rios, C. A., Williams, C. D. \& Apperley, D. C. Synthesis and characterization of zeotype ANA framework by hydrothermal reaction of natural clinker. Fuel 88, 272-281 (2009).

38. Ma, X., Yang, J., Ma, H., Liu, C. \& Zhang, P. Synthesis and characterization of analcime using quartz syenite powder by alkalihydrothermal treatment. Microporous Mesoporous Mater. 201, 134-140 (2015).

39. Yuan, J., Yang, J., Ma, H., Liu, C. \& Zhao, C. Hydrothermal synthesis of analcime and hydroxycancrinite from k-feldspar in $\mathrm{Na}_{2} \mathrm{SiO}_{3}$ solution: Characterization and reaction mechanism. RCS Adv. 6(59), 54503-54509 (2016).

40. Atta, A. Y., Jibril, B. Y., Aderemi, B. O. \& Adefila, S. S. Preparation of analcime from local Kaolin and rice husk ash. Appl. Clay Sci. 61, 8-13 (2012).

41. Jamil, T. S. \& Youssef, H. F. Microwave synthesis of zeolites from Egyptian kaolin: Evaluation of heavy metals removal. Sep. Sci. Technol. 52(18), 2876-2886 (2016).

42. Navickas, A. A., Spokauskas, A. A. \& Stuopys, A. Factors that influence analcime formation. Geologija 42, 19-25 (2003).

43. Novembre, D., Di Sabatino, B., Gimeno, D. \& Pace, C. Synthesis and characterization of Na-X, Na-A and Na-P zeolites and hydroxysodalite from metakaolinite. Clay Miner. 46, 336-354 (2011).

44. Novembre, D., Di Sabatino, B. \& Gimeno, D. Synthesis of Na-A zeolite from $10 \AA$ halloysite and a new crystallization kinetic model for the transformation of Na-A into HS zeolite. Clay Clay Miner. 53(1), 28-36 (2005).

45. Novembre, D., Gimeno, D., Pasculli, A. \& Di Sabatino, B. Synthesis and characterization of sodalite using natural kaolinite: An analytical and mathematical approach to simulate the loss in weight of chlorine during the synthesis process. Fresen. Environ. Bull. 19(6), 1109-1117 (2010).

46. Novembre, D., Pasculli, A., Pace, C., Gimeno, D. \& DiSabatino, B. Synthesis of sodalite from natural kaolinite. A way to simulate the loss in weight of chlorine during synthesis process by an analytical and mathematical modelling. Rend. Online Soc. Geol. It. 11(2), 548-549(2010).

47. Novembre, D., Gimeno, D., d'Alessandro, N. \& Tonucci, L. Hydrothermal synthesis and characterization of kalsilite by using a kaolinitic rock from Sardinia, Italy, and its application in the production of biodiesel. Mineral. Mag. 82(4), 961-973 (2018).

48. Novembre, D., Gimeno, D. \& Del Vecchio, A. Improvement in the synthesis conditions and studying the physicochemical properties of the zeolite Li-A(BW) obtained from a kaolinitic rock. Sci. Rep. 10(1), 5715-5723 (2020).

49. Novembre, D., Gimeno, D. \& Del Vecchio, A. Synthesis and characterization of Na-P $($ GIS) zeolite using a kaolinitic rock. Sci. Rep. 11, 4872-4883 (2021).

50. Rios, C. A., Williams, C. D. \& Maple, M. J. Synthesis of zeolites and zeotypes by hydrothermal transformation of kaolinite and metakaolinite. Bistua 5(1), 15-26 (2007).

51. Moraes, C. G., Rodrigues, E. C., Angelica, R. S., Macedo, E. N. \& Neves, R. F. Analcime zeolite production from amazon kaolin. Ceramica 59, 563-569 (2013).

52. Kwakye, B., Von-Kiti, E., Buamah, R., Nkrumah, I. \& Williams, C. Effect of crystallization time on the hydrothermal synthesis of zeolites from kaolin and bauxite. IJSER 5(2), 734-741 (2014).

53. Abdul-Monheim, M., Abdelmoneim, A. A., Geies, A. A. \& Farghaly, S. O. Synthesis, characterization of analcime and its application in water treatment from heavy metal. Ass. Univ. Bull. Environ. Res. 21(1), 1-22 (2018).

54. Larson, A. C. \& Von Dreele, R. B. GSAS: General Structure Analysis. System Document Laur 86-748 (Los Alamos National Laboratory, 1997).

55. Toby, B. H. EXPGUI, a Graphical User Interface for GSAS. J. Appl. Crystallogr. 34, 210-213 (2001).

56. Gatta, G. D., Nestola, F. \& Ballaran, T. B. Elastic behaviour, phase transition, and pressure induced structural evolution of analcime. Am. Mineral. 91, 568-578 (2006).

57. Novembre, D., Di Sabatino, B., Gimeno, D., Garcia Valles, M. \& Martinez-Manent, S. Synthesis of Na-X zeolites from tripolaceous deposits (Crotone, Italy) and volcanic zeolitized rocks (Vico Volcano, Italy). Microporous Mesoporous Mater. 75, 1-11 (2004).

58. Novembre, D. \& Gimeno, D. The solid-state conversion of kaolin to KAlSiO4 minerals: the effects of time and temperature. Clays Clay Min. 65(5), 355-366 (2017).

59. Novembre, D., Gimeno, D. \& Poe, B. Synthesis and characterization of leucite using a diatomite precursor. Sci. Rep. 9, 10051-10061 (2019).

60. Novembre, D., Pace, C. \& Gimeno, D. Syntheses and characterization of zeolites K-F and W type using a diatomite precursor. Mineral. Mag. 78, 1209-1225 (2014).

61. Barrer, R. M. \& Munday, B. M. Cation exchange in the synthetic zeolite K-F. J. Chem. Soc. A 2914-2921 (1971).

62. Belver, C. \& Vicente, M. A. Easy synthesis of K-F zeolite from kaolin, and characerization of this zeolite. J. Chem. Educ. 83(10), 1541-1542 (2006).

63. Mozgawa, W. The relation between structure and vibrational spectra of natural zeolites. J. Mol. Struct. 596, 129-137 (2001).

64. Blanco, C. et al. Differences between one aluminoc Palygorskite and another magnesic by infrared spectroscopy. J. Spectrosc. Lett. 22(9), 659-673 (1989).

65. Rios-Reyes, C. A., Williams, C. \& Castellanos-Alarcos, O. M. Nucleationand growth process of sodalite and cancrinite from kaolinite-rich clay under low-temperature hydrothermal conditions. J. Mater. Res. 16(2), 424-438 (2013).

\section{Acknowledgements}

The authors greatly acknowledge the technical staff at CCiT (UB) for their help during the development of the work. 


\section{Author contributions}

D.N. and D.G. wrote the main manuscript text and D.N. prepared all figures and Table 1. All authors reviewed the manuscript.

\section{Competing interests}

The authors declare no competing interests.

\section{Additional information}

Correspondence and requests for materials should be addressed to D.N.

Reprints and permissions information is available at www.nature.com/reprints.

Publisher's note Springer Nature remains neutral with regard to jurisdictional claims in published maps and institutional affiliations.

(c) (i) Open Access This article is licensed under a Creative Commons Attribution 4.0 International License, which permits use, sharing, adaptation, distribution and reproduction in any medium or format, as long as you give appropriate credit to the original author(s) and the source, provide a link to the Creative Commons licence, and indicate if changes were made. The images or other third party material in this article are included in the article's Creative Commons licence, unless indicated otherwise in a credit line to the material. If material is not included in the article's Creative Commons licence and your intended use is not permitted by statutory regulation or exceeds the permitted use, you will need to obtain permission directly from the copyright holder. To view a copy of this licence, visit http://creativecommons.org/licenses/by/4.0/.

(C) The Author(s) 2021 